\title{
Multiple intraventricular neurocysticerci
}

Figure 1 Axial T1-weighted images show intraventricular cystic lesions

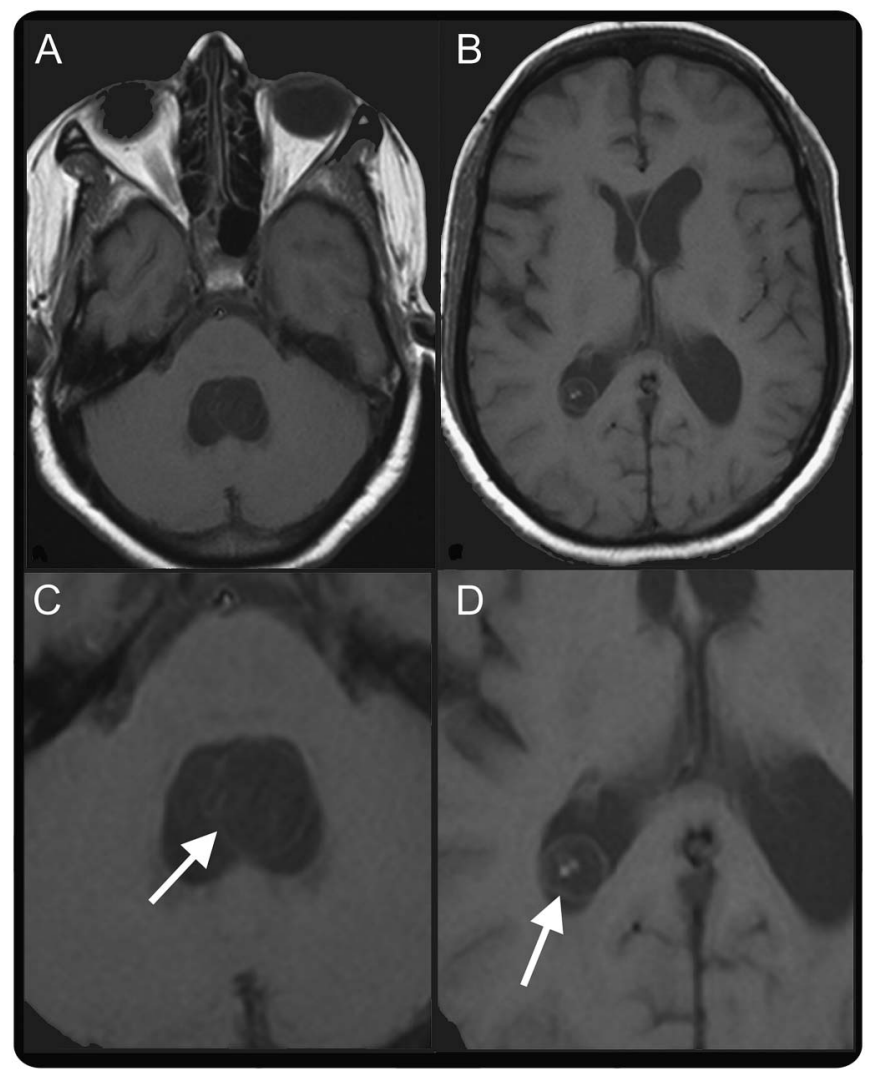

Axial T1-weighted images ( $A$ and $B$ ) show dilation of ventricular system with conspicuous rounded contour of fourth ventricle. Closer look reveals thin wall (arrows in the enlarged images $C$ and $D$ ) of the cystic lesions within the ventricles.

An otherwise healthy 35-year-old woman presented with a 1-year history of headache, a holocranial dull ache with 1 to 2 episodes per month, each lasting 1 to 2 hours. There was no photophobia, phonophobia, nausea, vomiting, fever, seizure, or loss of consciousness. In the month before presentation, headache became severe and continuous. Neurologic examination revealed bilateral papilledema. MRI showed multiple intraventricular neurocysticercal cysts in the fourth and right lateral ventricles with scolices (figures 1 and 2 ). Such a finding has been reported rarely in the literature. ${ }^{1}$ Treatment options include surgery (ventriculostomy or shunt; cystectomy) or medical management (cysticidal agents, corticosteroids, antiepileptic drugs). ${ }^{2}$

Deepti Vibha, MD, DM, Vipin Ola, MD, Madhuri Behari, MD, DM, Vinay Goyal, MD, DM, Garima Shukla, $M D, D M, S$. Leve Joseph Devarajan, $M D, D M$

From the All India Institute of Medical Sciences, New Delhi, India.

Author contributions: Deepti Vibha: drafting/revising the manuscript, study concept or design, analysis or interpretation of data, accepts responsibility for conduct of research and will give final approval, acquisition of data. Vipin Ola: drafting/revising the manuscript, accepts responsibility for conduct of research and will give final approval, acquisition of data. Madhuri Behari: drafting/revising the manuscript, study concept or design, analysis or interpretation of data, accepts responsibility for conduct of research and will give final approval, study supervision. Vinay Goyal: study concept or design, accepts responsibility for conduct of research and will give final approval, study supervision. Garima Shukla: study concept or design, accepts responsibility for conduct of research and will give 


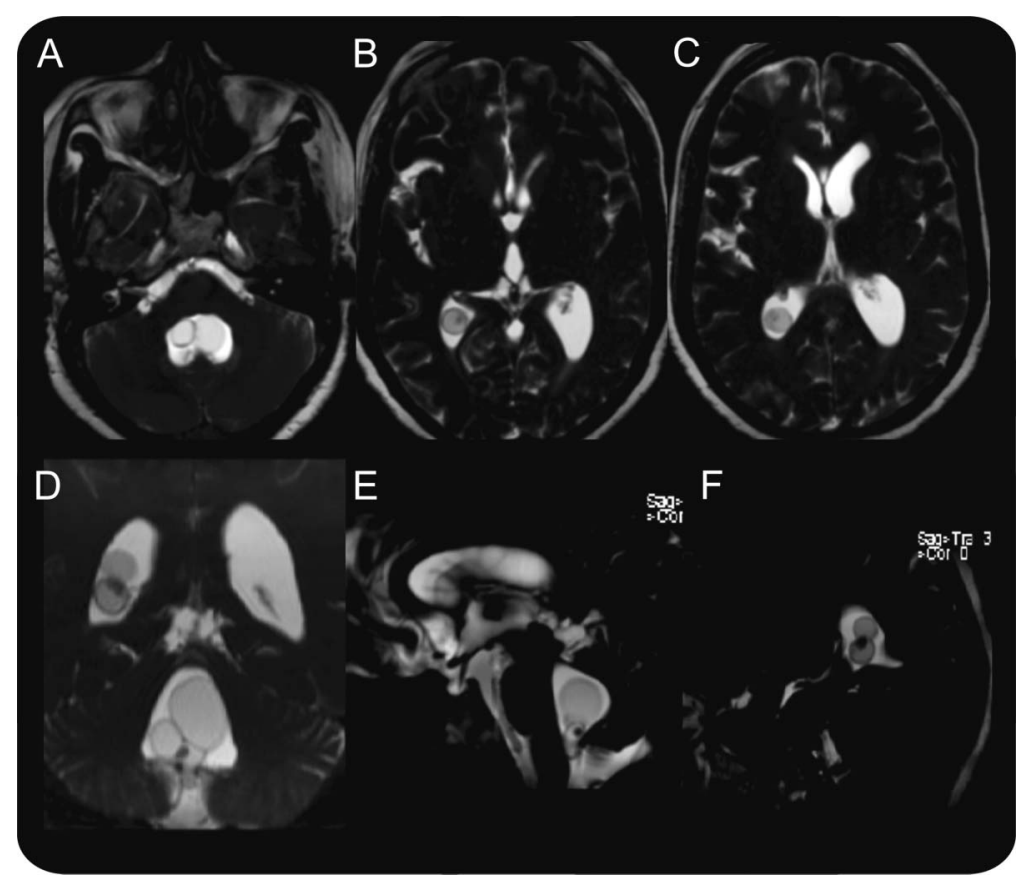

CISS sequence with reformatted images in axial $(A-C)$, coronal $(D)$, and sagittal $(E$ and $F)$ planes clearly depicts the conglomerate cystic lesions within the fourth and right lateral ventricles. The hypointense eccentric nodules within the cysts represent scolices. The contents of the cyst are slightly hypointense to the CSF (C-F).

final approval, study supervision. S. Leve Joseph Devarajan: drafting/revising the manuscript, study concept or design, analysis or interpretation of data, accepts responsibility for conduct of research and will give final approval, acquisition of data, study supervision. Study funding: No targeted funding reported.

Disclosure: The authors report no disclosures relevant to the manuscript. Go to Neurology.org for full disclosures.

Correspondence to Dr. Vibha: deeptivibha@yahoo.com

1. Kelesidis T, Thian N. Multiple intraventricular neurocysticercal cysts treated with endoscopy without antiparasitic therapy. Am J Trop Med Hyg 2011;85:1-2.

2. Sinha S, Sharma BS. Intraventricular neurocysticercosis: a review of current status and management issues. Br J Neurosurg 2012; 26:305-309.

\section{NeuroImages Are Free at www.neurology.org!}

All Neurology ${ }^{\circledR}$ NeuroImages can now be freely accessed on the Neurology Web site. See them at www.neurology.org, where you can also sign up for journal email alerts and check out other online features, including the Resident \& Fellow section, Neurology: Clinical Practice, and the weekly Neurology Podcasts. 


\title{
Neurology
}

\author{
Multiple intraventricular neurocysticerci \\ Deepti Vibha, Vipin Ola, Madhuri Behari, et al. \\ Neurology 2013;81;936-937 \\ DOI 10.1212/WNL.0b013e3182a3524c
}

This information is current as of September 2, 2013

\section{Updated Information \& Services}

\section{References}

Subspecialty Collections

Permissions \& Licensing

Reprints including high resolution figures, can be found at: http://n.neurology.org/content/81/10/936.full

This article cites 2 articles, 1 of which you can access for free at: http://n.neurology.org/content/81/10/936.full\#ref-list-1

This article, along with others on similar topics, appears in the following collection(s):

MRI

http://n.neurology.org/cgi/collection/mri

Parasitic infections

http://n.neurology.org/cgi/collection/parasitic_infections

Secondary headache disorders

http://n.neurology.org/cgi/collection/secondary_headache_disorders

Information about reproducing this article in parts (figures,tables) or in its entirety can be found online at:

http://www.neurology.org/about/about_the_journal\#permissions

Information about ordering reprints can be found online:

http://n.neurology.org/subscribers/advertise

Neurology ${ }^{\circledR}$ is the official journal of the American Academy of Neurology. Published continuously since 1951, it is now a weekly with 48 issues per year. Copyright @ 2013 American Academy of Neurology. All rights reserved. Print ISSN: 0028-3878. Online ISSN: 1526-632X.

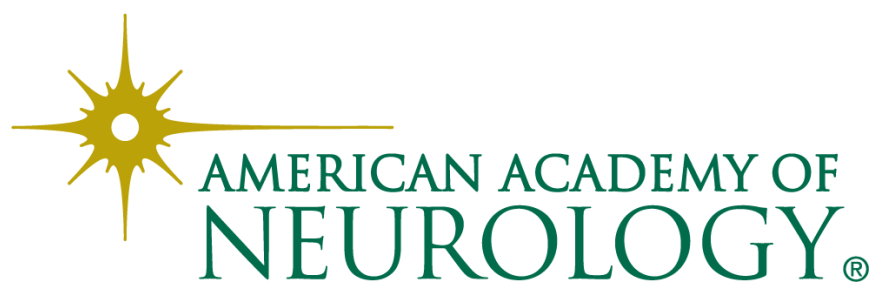

